\title{
МІСЦЕ КРЕАТИВНОСТІ У ПРОФЕСІЙНОМУ ЗРОСТАННІ ПЕДАГОГА-МУЗИКАНТА
}

\author{
Міщенко С. П. \\ концертмейстер кафедри теорії і методики музичної освіти та хореографії \\ Мелітопольський держсавний педагогічний університет імені Богдана Хмельнииького \\ вул. Гетьманська, 20, Мелітополь, Запорізька область, Украӥна \\ orcid.org/0000-0002-6690-9271 \\ svetik.piano@gmail.com
}

\author{
Ключові слова: креативність, \\ педагог-музикант, професійне \\ зростання, освітня \\ реальність педагогічного \\ закладу вищчої освіти.
}

У статті актуалізоване розуміння, що сьогодні одними 3 важливих напрямів реформування вищої освіти в Україні є гуманізація освітньої діяльності та спрямування навчально-виховного процесу 3 ВО на формування творчої особистості майбутнього фахівця, створення умов для розкриття здібностей, талантів та обдарувань студентів.

У ході вирішення проблеми пошуку місця креативності у професійній підготовці педагога-музиканта автор звертається до історичних основ виникнення цього поняття, досліджує перехід його 3 психології до педагогіки, аналізує існуючі концепції на наукові погляди на трактування поняття креативності.

Автором доведено, що творча особистість - це креативна особистість, яка внаслідок впливу зовнішніх чинників набула необхідних для актуалізації творчого потенціалу додаткових мотивів, особистісних утворень, здібностей, що сприяють досягненню творчих результатів в одному чи кількох видах творчої діяльності. У публікації зроблено висновок про те, що специфіка діяльності педагога-музиканта у своїй основі має креативний зміст. Творча діяльність педагога-музиканта зумовлює наявність у його структурі креативності як особистісної якості. Відомим $\epsilon$ той факт, що педагог-музикант відноситься до категорії творчих особистостей, а тому його креативність можна трактувати як невід'ємну особистісну властивість, що дає йому змогу реалізувати творчий потенціал у практичній діяльності (музикуванні, співі, учителюванні тощо).

Визначено, що креативність займає чільне місце в структурі особистості педагога-музиканта та $є$ важливою для його педагогічної діяльності. Проаналізовані концепції і підходи до вивчення феномена креативності дали змогу вибрати серед професійних якостей педагога-музиканта креативність як одну з провідних та важливих. Автор наголошує, що педагогічна діяльність педагога-музиканта у своїй сутті $є$ творчою, адже відзначається різноманітністю, складністю і специфікою предмета, що викладається. Вона має вміщувати вмотивованість до вибраної діяльності, розвинуті спеціальні здібності, інтелектуальну ініціативність та креативність як особистісну якість, що дасть змогу педагогу-музиканту самореалізуватися у творчості. 


\title{
THE PLACE OF CREATIVITY IN THE PROFESSIONAL GROWTH OF A MUSIC TEACHER
}

\author{
Mishchenko S. P. \\ Concertmaster at the Department of Theory and Methods \\ of Music Education and Choreography \\ Bogdan Khmelnytsky Melitopol State Pedagogical University \\ Hetmanska str., 20, Melitopol, Zaporizhzhia region, Ukraine \\ orcid.org/0000-0002-6690-9271 \\ svetik.piano@gmail.com
}

Key words: creativity, music teacher, professional growth, the educational reality of pedagogical institution of higher education.
The article actualizes the understanding that today one of the most important directions of higher education reform in Ukraine is the humanization of educational activities and the direction of the educational process of IHE (institution of higher education) on the formation of creative personality of the future specialist, creating conditions for discovering abilities, talents, and talents of students.

The author turns to the historical foundations of this concept, explores its transition from psychology to pedagogy, analyzes existing concepts from scientific points of view in interpreting the concept of creativity, in solving the problem of finding a place for creativity in the professional training of music teachers.

The author proves that an artistic personality is a creative personality, which due to the influence of external factors has acquired the necessary additional motives for personalization of creative potential, personal formations, abilities that contribute to creative results in one or more creative activities. The publication concludes that the specifics of the teacher-musician has a creative meaning. The creative activity of a music teacher determines the presence of creativity in his structure as a personal quality. It is a well-known fact that a music teacher belongs to the category of creative personalities, and therefore his creativity can be interpreted as an integral personal property that allows him to realize his creative potential in practice (music, singing, teaching, etc.). It is determined that creativity occupies a prominent place in the personality structure of a music teacher and is important for his pedagogical activity. The analyzed concepts and approaches to the study of the phenomenon of creativity allowed to choose among the professional qualities of a music teacher creativity as one of the leading and important. The author of the article emphasizes that the pedagogical activity of a music teacher is inherently creative, as it is marked by the diversity, complexity, and specificity of the subject taught. It should include motivation for the chosen activity, developed special abilities, intellectual initiative, and creativity, as a personal quality that will allow the teacher-musician to realize himself in art.
Постановка проблеми. Сьогодні одними 3 важливих напрямів реформування вищої освіти в Україні є гуманізація освітньої діяльності та спрямування навчально-виховного процесу ЗВО на формування творчої особистості майбутнього фахівця, створення умов для розкриття здібностей, талантів та обдарувань студентів.

Освітня реальність закладів вищої освіти України відображає вимоги МОН до якості освітніх послуг, що надаються державою здобува- чам вищої освіти. Спираючись на перелік освітніх документів, серед яких: Закон України «Про освіту» (оновлений 2017 р.), Закон України «Про вищу освіту» (зі змінами 2021 р.), Закон України «Про підготовку науково-педагогічних і наукових кадрів», Національна доктрина розвитку освіти України в XXI ст., Національна стратегія розвитку освіти в Україні на 2012-2021 рр., Концептуальні засади розвитку педагогічної освіти в Україні та іiі інтеграції в європейський освітній про- 
стір (2004 р., оновлено 2020 р.) та ін. [2], можна актуалізувати проблему професійного зростання педагога-музиканта, оновлення підходів, методів і форм мистецького навчання у ЗВО та місця креативності у професії педагога-музиканта.

Мета статті - визначити місце і сутність креативності у структурі особистості педагога-музиканта під час його професійного становлення.

Виклад основного матеріалу дослідження. У ході вирішення проблеми пошуку місця креативності у професійній підготовці педагога-музиканта ми звернулися до історичних основ виникнення цього поняття, переходу його з психології до педагогіки, існуючих підходів на наукових поглядів на його трактування.

Дослідженням проблеми креативності у структурі особистості займалися західноєвропейські психологи Дж. Гілфорд, В. Келлер, П.Е. Торранс, Е.Фромтаін.,увітчизнянійпсихології-О.Брушлинський, 3. Калмикова, Я. Пономарьов, С. Рубінштейн тощо. Креативність як особистісний феномен цікавить таких дослідників, як В. Дружинін, Л. Срмолаєва-Томіна, М. Козленко, М. Лещенко, О. Лук, В. Моляко, В. Пєтухов, К. Тошина та ін.

Н. Вишнякова, Г. Мєднікова, Н. Яременко та інші вчені розглядають феномен креативності в контексті вивчення творчості, порівнюючи їхні спільні та відмінні риси. Питанням практичної підготовки майбутніх педагогів-музикантів та творчому аспекту їхньої професійної самореалізації присвячено розвідки Л. Арчажникової, I. Боднарук, В. Бриліної, Г. Падалки, А. Козир, Н. Сегеди та ін.

Термін «креативність» набуває поширення у педагогіці та психології у 60-х роках ХХ ст. завдяки дослідженням Дж. Гілфорда. Учений упродовж багатьох років досліджував інтелектуальні здібності людини та інтелектуальну структуру особистості і зробив висновок про існування дивергентного мислення, яке породжує безліч різних варіантів розв'язання проблемної ситуації та виявляється у процесі розв'язання завдань, що припускають існування безлічі правильних відповідей. Такий тип мислення Дж. Гілфорд називав дивергентним і пов'язував його із мисленнєвими вміннями продукування ідей, пошуком декількох шляхів вирішення одного й того самого завдання. Учений уважав, що саме таке мислення є основою креативності [4].

О. Антонова, визначаючи особливості дивергентного мислення (за Дж. Гілфордом), класифікує їх так:

- легкість і продуктивність - наскільки швидко індивід може створювати певні продукти творчості (ідеї, думки, об'єкти тощо);

- гнучкість - здатність швидко переключатися з однієї проблеми на іншу або об'єднувати їх;
- оригінальність - своєрідність мислення, незвичний підхід до проблеми, її нове вирішення;

- точність (відповідність) - стрункість розумових операцій щодо тієї чи іншої проблеми, вибір рішення, адекватного поставленій меті [1, с. 12].

С. Терещенко, досліджуючи проблему креативності як особистісної якості, здатної до самовираження у творчості завдяки розвинутим асоціативно-образному мисленню, творчій уяві та художній спостережливості, робить аналіз наукових праць класиків вітчизняної педагогіки, серед яких Д. Богоявленська, В. Зягвязинський, В. Кан-Калік, Н. Кузьміна та ін. Авторка виражає думку про те, що згадані науковці зверталися у своїх працях до проблеми творчого розвитку особистості, наголошуючи, що іiі структура має динамічну основу i включає комплекс творчих задатків, які проявляються у творчій активності особистості та зумовлюються креативністю [7].

П.Е. Торренс визначає креативність як «творчі можливості людини, що можуть виявлятися у мисленні, почуттях, спілкуванні, окремих видах діяльності» [9]. Ми, звичайно, погоджуємося 3 думкою фундатора креативності як особистісного феномена і додаємо, що креативною може бути будь-яка життєва ситуація, в якій є новизна та неординарність. Необхідними умовами для прояву креативності $\epsilon$ наявність творчих цінностей, творчої особистості, творчого процесу, творчих умінь та творчого мислення, пізнавальних інтересів, відхилення від шаблону в поведінці, швидкість реагування, гнучкість мислення, передбачення вирішення ситуації, високий ступінь активності в розумовій діяльності [9].

А. Савенков, спираючись на досвід західноєвропейських психологів, наводить категорії особистісних здатностей, за якими можна оцінити креативність. Серед них:

- продуктивність та швидкість - здатність до продукування максимально великої кількості ідей. Цей показник не є специфічним для творчості, однак чим більше ідей, тим більше можливостей для вибору з них найбільш оригінальних;

- гнучкість - здатність легко переходити від явищ одного класу до явищ іншого класу, часто дуже далеких за змістом один від одного. Протилежну якість називають інертністю мислення;

- оригінальність - здатність висувати нові й несподівані ідеї, що відрізняються від широко відомих, загальноприйнятих, банальних;

- розробленість - здатність до творчої самореалізації (в улюбленій справі, професії) [5, с. 26].

Аналізуючи праці А. Тейлора, Н. Латипов звертає увагу на деякі рівні здібностей людини до творчості, виокремлені автором у процесі дослідження проблеми креативності, серед яких - академічний, винахідницький та іннова- 
ційний. Автор наголошує, що на академічному рівні креативності особистість, високоерудована у певній сфері та галузі, вміє застосовувати на практиці різні методики, має достатню вмотивованість і рівень досвіду для реалізації власних ідей. Такі люди досконало володіють знаннями, які вміло поєднують із творчою енергією. Щодо винахідницького рівня, його автор трактує як безмежний простір для реалізації творчих можливостей особистості у межах діяльності, якою він займається, уміння поєднувати знання, підходи, загальновідомі факти для створення чогось нового та оригінального. Рівень інновацій належить особистостям творчих професій (актори, музиканти, письменники), які здатні втілити дотепер не існуючі ідеї та підходи до вирішення проблеми. Цей рівень, на переконання автора, керується креативними зусиллями особистості [3, c. 120-121].

Нам імпонують вищевикладені думки авторів щодо феномена креативності, адже специфіка діяльності педагога-музиканта у своїй основі має креативний зміст. Творча діяльність педагога-музиканта зумовлює наявність у його структурі креативності як особистісної якості. Відомим є той факт, що педагог-музикант належить до категорії творчих особистостей, а тому його креативність можна трактувати як невід'ємну особистісну властивість, що дає йому змогу реалізувати творчий потенціал у практичній діяльності (музикуванні, співі, учителюванні тощо).

Дослідниця педагогічної креативності С. Сисоєва виділяє такі її ознаки: високий рівень соціальної і моральної свідомості; пошуково-перетворюючий стиль мислення; розвинені інтелектуально-логічні здібності (вміння аналізувати, обгрунтовувати, пояснювати, виділяти головне тощо); проблемне бачення; творча фантазія, розвинута уява; специфічні особистісні якості (любов до дітей, безкорисливість, сміливість, готовність до розумного ризику в професійній діяльності, цілеспрямованість, допитливість, самостійність, наполегливість, ентузіазм); специфічні мотиви (необхідність реалізувати своє «Я», бажання бути визнаним, творчий інтерес, захопленість твор- чим процесом, своєю працею, прагнення досягти найбільшої результативності в конкретних умовах педагогічної праці); комунікативні здібності; здатність до самоуправління; високий рівень загальної культури [6, с. 98-99].

Для того щоб людина відбулася як особистість творча, необхідно, щоб у неї була розвинута внутрішня передумова до творчої діяльності [8]. На основі цього можна визначити психологічну суть творчого потенціалу особистості через такі складники, як творчі здібності, творча активність та креативність. Творча особистість - це креативна особистість, яка внаслідок впливу зовнішніх чинників набула необхідних для актуалізації творчого потенціалу додаткових мотивів, особистісних утворень, здібностей, що сприяють досягненню творчих результатів в одному чи кількох видах творчої діяльності.

Музиканти як творчі особистості можуть виявляти здатність до генерування ідей, використовуючи для вирішення проблеми незвичайні, нестандартні, унікальні методи і прийоми, надзвичайно емоційні і чуттєві, схильні до відтворення власних переживань звуками музики.

Висновки i перспективи подальших розвідок у цьому напрямі. Отже, креативність займає чільне місце у структурі особистості педагога-музиканта та $\epsilon$ важливою для його педагогічної діяльності. Проаналізовані концепції і підходи до вивчення феномена креативності дали змогу вибрати серед професійних якостей педагога-музиканта креативність як одну з провідних та важливих. Педагогічна діяльність педагога-музиканта у своїй сутті $€$ творчою, адже відзначається різноманітністю, складністю і специфікою предмета, що викладається. Вона має вміщувати вмотивованість до вибраної діяльності, розвинуті спеціальні здібності, інтелектуальну ініціативність та креативність як особистісну якість, що дасть змогу педагогу-музиканту самореалізуватися у творчості.

До перспектив подальших досліджень відносимо визначення структури креативності педагога-музиканта під час його професійного становлення у педагогічному закладі вищої освіти. 


\section{ЛІТЕРАТУРА}

1. Антонова О.С. Педагогічна креативність у структурі педагогічної обдарованості вчителя. Нові технології навчання : науково-методичний збірник / Ін-т інноваційних технологій і змісту освіти МОНМС України, Академія міжнародного співробітництва з креативної педагогіки. 2011. Вип. 69. Ч. 2. С. $11-17$.

2. Законодавча освітня база України. URL: http://zakon3.rada.gov.ua/laws/show/651-14.

3. Минута на размышление. Основы интеллектуального тренинга. URL: https://altairbook.com/ books/1953351-osnovy-intellektualnogo-treninga-minuta-na-razmyshlenie.html.

4. Павлюк Р.О. Креативність як складова частина професійної підготовки майбутніх учителів. URL: http://www.rusnauka.com/16_NPM_2007/Pedagogica/22154.doc.htm.

5. Савенков А.И. Основные подходы к разработке концепции одарённости. Педагогика. 1998. № 3. C. 24-29.

6. Сисоєва С.О. Основи педагогічної творчості. 2006. 346 с.

7. Терещенко С.B. Розвиток креативності підлітків на інтегрованих уроках музики. URL: https://npu.edu.ua/images/file/vidil_aspirant/dicer/D_26.053.08/dis_Tereschenko.pdf.

8. Терещук А. Креативність як невід'ємний компонент інтелектуального розвитку особистості. URL: http://www.newacropolis.org.ua/ua/study/conference/?thesis=4254. 12. Stain B.S. Memory and Creativity // Handbook of Creativity. Ed. of J.A. Glover and other. Plenum Press, N.Y. and London. 1988.

9. Torrance Center for Creativity and Talent Development. URL: https://coe.uga.edu/directory/ torrance-center.

\section{REFERENCES}

1. Antonova O.C. (2011) Pedagogichna kreativnist' u strukturi pedagogichnoï obdarovanosti vchitelya. [Pedagogical creativity in the structure of teacher pedagogical talent]. New learning technologies: Scientific method. zb. / Inst of Innovation technologies and content of education of the Ministry of Education and Science of Ukraine, Academy of International cooperation in creative pedagogy. Vol. 69. P. 11-17.

2. Zakonodavcha osvitnya baza Ukraïni [Legislative educational base of Ukraine]. Rezhim dostupa: http://zakon3.rada.gov.ua/laws/show/651-14.

3. Minuta na razmyshlenie. Osnovy intellektual'nogo treninga. [Minutes of reflection. basics of intellectual creativity]. Rezhim dostupu : https://altairbook.com/books/1953351-osnovy-intellektualnogo-treninga-minuta-na-razmyshlenie.html

4. Pavlyuk R.O. Kreativnist' yak skladova chastina profesijnoï pidgotovki majbutnih uchiteliv [Creativity as an integral part of professional training of future teachers]. Rezhim dostupu : http://www.rusnauka. com/16_NPM_2007/Pedagogica/22154.doc.htm.

5. Savenkov A.I. (1998). Osnovnye podhody k razrabotke koncepcii odaryonnosti. [Basic approaches to the development of the concept of giftedness].Pedagogika. № 3. P. 24-29.

6. Siso€va S.O. (2006). Osnovi pedagogichnoï tvorchosti. [Fundamentals of pedagogical creativity]. 346 p.

7. Tereshchenko S.V. (2018). Rozvitok kreativnosti pidlitkiv na integrovanih urokah muziki [Development of creativity of teenagers in integrated music lessons]. Rezhim dostupu : https:/npu.edu.ua/images/file/ vidil_aspirant/dicer/D_26.053.08/dis_Tereschenko.pdf.

8. Tereshchuk A. Kreativnist' yak nevid'€mnij komponent intelektual'nogo rozvitku osobistosti [Creativity as an integral component of intellectual development]. Rezhim dostupu : http://www.newacropolis.org.ua/ ua/study/conference/?thesis=4254. 12. Stain B.S. Memory and Creativity. Handbook of Creativity. Ed. of J.A. Glover and other. Plenum Press, N.Y. and London. 1988.

9. Torrance Center for Creativity and Talent Development. Rezhim dostupu : https://coe.uga.edu/directory/ torrance-center. 